УДК 332.3

DOI https://doi.org/10.37687/2413-7189.2020.1.7

Люльчик В.О.,
кандидат сільськогосподарських наук,
завідувач технічного відділення
ВСП «Рівненський коледж Національного університету біоресурсів і природокористування України»

ORCID: 0000-0001-6360-6796

Русіна Н.Г.,

кандидат педагогічних наук,

голова циклової комісії землевпорядних дисциплін, викладач

ВСП «Рівненський коледж Національного університету біоресурсів і природокористування України»

ORCID: 0000-0001-5826-8788

Кийко Н.М., викладач

ВСП «Рівненський коледж Національного університету біоресурсів і природокористування України» ORCID: 0000-0002-1602-4184

\title{
Кушнірук О.М.,
}

викладач

ВСП «Рівненський коледж Національного університету біоресурсів і природокористування України» ORCID: 0000-0003-0054-3956

\section{Рудько О.М.,}

викладач

ВСП «Рівненський коледж Національного університету біоресурсів і природокористування України» ORCID: 0000-0002-2579-6792

\section{ПРАВОВИЙ РЕЖИМ ПОЛЕЗАХИСНИХ ЛІСОВИХ СМУГ І ЗЕМЕЛЬНИХ ДІЛЯНОК ПІД НИМИ: ТЕОРЕТИКО-ПРАВОВІ АСПЕКТИ}

\section{LEGAL REGIME OF PROTECTED FOREST STRIPS AND LAND PLOTS UNDER THEM: THEORETICAL AND LEGAL ASPECTS}

У статті представлено аналіз змін у сучасному законодавстві України, щзо регулюють відносини, пов'язані з охороною та використанням полезахисних лісових смуг $і$ земельних ділянок під ними. Метою статті є аналіз норм сучасного законодавства шодо земельного, лісового й екологічного аспектів права користування земельними ділянками захисних лісових насаджень, а особливо польових лісових смуг. Встановлено, щзо полезахисні лісові смугами належсать до агролісотехнічної меліоращіï, за функціональним призначенням розділяються на дві групи. Зазначено, щчо змінами в чинному законодавстві встановлено правовий режсим земельних ділянок під полезахисними лісовими смугами. Землі під лісосмугами перебувають у комунальній власності. Визначено порядок та умови передачі їх у користування. Механізм формування земельних ділянок під полезахисними лісовими смугами визначений земельним законодавством, під час проведення інвентаризації масиву земель сільськогосподарського призначення здійснюються заходи щодо формування земельних ділянок сільськогосподарського призначення під полезахисними лісовими смугами та іншими захисними насадженнями, які обмежують масив і земельні ділянки, розташовані вздовж масиву. У постійне користування землі передаються виключно спечіалізованим підприємствам комунальної та державної форм власності. Землі під лісосмугами передаються у постійне користування та в оренду. В оренду земельні ділянки під лісосмугами можуть передаватися будь-якій фізичній чи юридичній особі за умови обов 'язкового догляду за лісосмугою. Оренда здійснюватиметься так само, як і отримання в оренду будь-якої земельної ділянки лише з тою відмінністю, цуо в договорі оренди зазначатимуться умови щодо необхідності утримання саме лісосмуги. Надання в оренду земельних ділянок під полезахисними лісовими смугами, шо обслуговують масив земель сільськогосподарського призначення, здійснюється без проведення конкурсу. Правилами утримання лісосмуг визначається процедура утримання та збереження полезахисних лісових смуг, розташованих на землях сільськогосподарського призначення. Виокремлено основні положення змін у законодавстві, вказано переваги та недоліки правового регулювання суспільних відносин у цій сфері.

Ключові слова: земельна ділянка, полезахисні лісові смуги, колективна власність, правове регулювання, оренда землі, інвентаризація земель. 
The article presents an analysis of changes in the modern legislation of Ukraine that regulate relationships associated with the protection and using field-protected forest strips and land plots under them. The purpose of the article is to analyze the norms of modern legislation on land, forest and environmental aspects of the right to use land plots of protective forest plantations, and especially field forest strips. It is established that the protective forest strips belong to agro forest-technical land reclamation (melioration), and are divided into two groups for their functional purpose. It is indicated that with changes in the current legislation, the legal regime of land plots under field-protected forest stripes has been established. Land under the forest is in communal ownership. The procedure and conditions for transferring them to use are defined. The mechanism of formation of land plots under field protective forest strips is determined by the land legislation that during the inventory of agricultural land mass measures are taken to form agricultural land plots under field forest protection strips and other protective plantings that limit the massif and land plots located along. For permanent use, land is transferred exclusively to specialized enterprises communal (municipal) and state forms of ownership. Land under the forest is transferred to permanent use and lease. Land plots under forest belts can be leased to any individual or legal person, provided that the forest stripe care is obligatory. The rental fee will be carried out in the same way as the lease of any land plot, with a difference, the lease agreement will determine the conditions of maintenance exactly the forest belt is compulsory. Leasing of land plots under protective forest strips serving an array of agricultural lands is carried out without a tender. The rules for maintaining forest belts determine the procedure for retaining and preserving protective forest strips located on agricultural land. The main conditions of changes in legislation are highlighted, and the advantages and disadvantages of legal regulation the social relation in this sphere are indicated.

Key words: land plot, field-protected forest strips, collective property, legal regulation, land rent, land inventory.

Постановка проблеми. Щорічні втрати зерна через ерозію грунтів в Україні становлять 10-12 млн тонн. Основними причинами таких втрат фахівці визначають занедбаний стан полезахисних лісосмуг. Протягом двадцяти років земельної реформи у країні полезахисним лісосмугам не приділялася належна увага. Відсутність нормативно-правової бази щодо визначення їх правого статусу гальмувала процеси створення, поновлення та догляду захисних насаджень. Зауважимо, в Україні кожен другий гектар лісу створений людиною. Упродовж останніх 50 років минулого століття в Україні було висаджено 440 тис. га полезахисних смуг, які захищали 13 млн га сільськогосподарських угідь. Науковцями було обгрунтовано, що один гектар лісосмуги захищає 20-30 га ріллі, врожай сільськогосподарських культур збільшується на $15 \%$. Сьогодні за статистичними даними в Україні обліковується близько 350 тис. га полезахисних і 90 тис. га водорегулюючих лісових смуг, що забезпечують захист $40 \%$ всієї ріллі, тобто дорівнює 13 млн га угідь [1].

Тому необхідно провести дослідження норм земельного законодавства, щоб з'ясувати, які зміни торкнулися правового регулювання питань використання та розпорядження земельними ділянками захисних лісових насаджень, чи усунуто колізії щодо належності земельних ділянок під лісосмугами, чи законодавчо закріплені підходи формування земельних ділянок під лісосмугами.

Стан наукового дослідження проблеми. Окремі аспекти дослідження використання земель лісових захисних насаджень були порушені у працях А. Годованюка, Г. Гладуна, Т. Євсюкова, М. Кочерги, А. Любчича, І. Опенько, О. Петровича, Д. Піддубної, О. Савчука, Н. Сігітової, І. Сюйва, В. Юхновського та ін. Однак загалом це питання у літературі досліджено недостатньо.
Метою статті $\epsilon$ аналіз норм сучасного законодавства щодо земельного, лісового й екологічного аспектів права користування земельними ділянками захисних лісових насаджень, а особливо польових лісових смуг.

Виклад основного матеріалу. Виклад окресленої проблематики дослідження доцільно представити такими інформаційними блоками: 1) поняття «захисні лісові насадження»; 2) нові положення щодо правового статусу лісосмуг; 3) формування земельних ділянок під полезахисними лісовими смугами.

Розглянемо більш детально кожен інформаційний блок:

1) Поняття «захисні лісові насадження».

Законом України «Про меліорацію земель» № 1389-XIV від 14 січня 2000 р. визначено, що меліорація земель - це комплекс гідротехнічних, культуртехнічних, хімічних, агротехнічних, агролісотехнічних, інших меліоративних заходів, які здійснюються з метою регулювання водного, теплового, повітряного і поживного режиму грунтів, збереження і підвищення їх родючості та формування екологічно збалансованої раціональної структури угідь. Відповідно до умов проведення меліоративних заходів передбачено поділ меліорації земель за основними видами, такими як: гідротехнічна, культуртехнічна, хімічна, агротехнічна, агролісотехнічна [2]. Агролісотехнічна меліорація земель забезпечує докорінне поліпшення земель шляхом використання грунтозахисних, стокорегулюючих та інших властивостей захисних лісових насаджень. У наукових джерелах існує градація лісомеліоративних систем на площинні та лінійні, які мають характерні множині функції. Площинні (протиерозійні) захисні лісонасадження забезпечують захист земель від ерозії, а водних об'єктів - від виснаження та замулення через заліснення балок, ярів, крутосхилів, пісків та 
інших деградованих земель, а також прибережних захисних смуг і водоохоронних зон річок та інших водойм. Лінійні (полезахисні) лісонасадження задовольняють оптимальні екологічні умови вирощування сільськогосподарських рослин, такі як температура і вологість повітря і грунту, випаровування вологи і транспірація рослин. У свою чергу, вони поділяються на полезахисні та стокорегулюючі лісосмуги.

Крім того, захисні лісові насадження розділяють на категорії за їх функціональним призначенням, організацією та технологією проектування. Перша категорія захисних лісових насаджень включає ділянки суцільного заліснення, прибалкові та прияружні лісові смуги, насадження навколо населених пунктів, виробничих центрів, господарських дворів, ставків і водоймищ, уздовж внутрігосподарських магістральних шляхів і каналів. Ця група виділяється під час складання проекту організації угідь і має санітарно-гігієнічні, рекреаційні й естетичні властивості та цілі. Полезахисні, водорегулюючі та вітроломні лісосмуги, а також лісосмуги для захисту багаторічних насаджень і насадження на пасовищах («зонти») утворюють другу категорію [3]. Крім того, окремим видом захисних насаджень можна виділити спеціальні, призначені для запобігання проявів несприятливих природних факторів за певних умов і на певних територіях. До них відносять: лісові смуги на зрошуваних і осушуваних землях; захисні насадження вздовж шляхів транспорту; лісові смуги для захисту садів, виноградників, розсадників, плантацій; насадження на непридатних (кам'янистих, піщаних тощо) землях.

Правова колізія питання колективної власності на землю стала головним бар'єром набуття правового статусу полезахисних лісових смуг і земельних ділянок під ними, адже під час процесу розпаювання було здійснено передачу земель у державну чи комунальну власність, але значна іiі частина так і залишалася у колективній власності. Відсутність такої форми власності, як колективна в конституційних засадах України викликала невідповідність у нормах земельного права. Як наслідок, землі під лісовими смугами та іншими захисними насадженнями фактично залишилися без власника, який мав здійснювати догляд за ними та сплачувати земельний податок [4].

2) Нові положення щодо правового статусу лісосмуг.

Закон України від 10 липня 2018 р. № 2498-VIII «Про внесення змін до деяких законодавчих актів України щодо вирішення питання колективної власності на землю, удосконалення правил землекористування у масивах земель сільськогосподарського призначення, запобігання рейдерству та стимулювання зрошення в Україні» (далі - Закон № 2498), який набрав чинності з 01 січня 2019 р., встановив низку нових правових норм, що поліпшать регулювання суспільних відносин у галузі використання й охорони полезахисних лісових смуг і земельних ділянок під ними [4].

Із прийняттям Закону № 2498 уперше на законодавчому рівні було встановлено правовий статус земельних ділянок під полезахисними лісовими смугами як землі сільськогосподарського призначення. Цей факт відображений у змінах до Земельного кодексу, а саме у п. «б» ч. 2 ст. 22 Земельного кодексу України: «до земель сільськогосподарського призначення належать несільськогосподарські угіддя (господарські шляхи і прогони, полезахисні лісові смуги та інші захисні насадження, крім тих, що віднесені до земель інших категорій, землі під господарськими будівлями i дворами, землі під інфраструктурою оптових ринків сільськогосподарської продукції, землі тимчасової консервації тощо)» [5]. Крім того, у лісовому законодавстві закріплено, що землі, на яких розташовані полезахисні лісові смуги, не належать до земель лісогосподарського призначення [6]. Однак ст. 4 Лісового кодексу України визначено, що до складу лісового фонду також належать захисні насадження лінійного типу, площа яких становить не менше 0,1 га. Нормативно-правові акти з ведення лісового господарства встановлюють порядок i вимоги до системи заходів 3 охорони, захисту, використання та відтворення лісів [6].

Питання передачі земельних ділянок під полезахисними лісовими смугами, які обмежують масив земель сільськогосподарського призначення, у постійне користування або в оренду було визначено законом № 2498, що призвело до ряду змін у Земельному кодексі України. Так, із 01 січня 2019 р. земельні ділянки під полезахисними лісовими смугами, що обмежують масив земель сільськогосподарського призначення, стали належати до комунальної власності [7]. Земельні ділянки під полезахисними лісовими смугами, які обмежують масив земель сільськогосподарського призначення, передаються у постійне користування державним або комунальним спеціалізованим підприємствам або в оренду фізичним i юридичним особам. Головна вимога такої передачі - обов'язкове включення до договору оренди землі умов утримання та збереження смуг i забезпечення виконання ними функцій агролісотехнічної меліорації [8]. Порядок передачі в користування земельних ділянок під полезахисними лісовими смугами відображено в доповненій ч. 7 ст. 37-1 ЗК України. Крім того, ст. 134 ЗКУ у новій редакції визначає: «не підлягають продажу на конкурентних засадах (земельних торгах) земельні ділянки державної чи комунальної власності або права на них у разі: надання в оренду земельних ділянок під полезахисними лісовими смугами, що обслуговують масив земель сільськогосподарського призначення» [8].

Та залишаються невирішеними питання [4]: 
1. Визначення переліку осіб, котрим можуть передаватися земельні ділянки під полезахисними лісовими смугами, адже вони можуть використовуватися кількома власниками або орендарями одночасно.

2. Передачі в оренду або постійне користування земельних ділянок під полезахисними лісовими смугами, що входять до масиву земель сільськогосподарського призначення, адже в земельному законодавстві не обгрунтовується їх правовий статус, а відповідно, і механізм передачі.

Відзначимо, що ефективність полезахисних лісових смуг залежить від їх догляду. Таким чином із 01 січня 2019 р. догляд за лісосмугами мають здійснювати за новими нормативами і правилами - це створення спеціалізованих підприємств, які здійснюватимуть догляд за лісосмугами, або надання повноважень вже існуючим комунальним організаціям із благоустрою територій, що знаходяться на балансі місцевих рад. Основним питанням догляду є рубка догляду та вибіркові санітарні рубки. Зазвичай вони мають проходити на нормами лісового законодавства та лісорубних квитків.

3) Формування земельних ділянок під полезахисними лісовими смугами.

Формування земельних ділянок сільськогосподарського призначення під полезахисними лісовими смугами та іншими захисними насадженнями, які обмежують масив і земельні ділянки, розташовані вздовж масиву, проходитиме під час проведення інвентаризації масиву земель сільськогосподарського призначення. Ця норма закріплена ст. 35 Закону України «Про землеустрій», доповненою ч. 4 [9]. Внесення інформації до Державного земельного кадастру про земельні ділянки під лісосмугами буде здійснено шляхом інвентаризації (рис. 1).
Роботи 3 інвентаризації земель здійснюватимуться за оплату суб'єктами господарювання, котрі мають необхідні ліцензії. Так, відповідно до постанови КМУ від 05 червня 2019 р. «Про затвердження Порядку проведення інвентаризації земель та визнання такими, що втратили чинність, деяких постанов Кабінету Міністрів України» виконавцями інвентаризації є юридичні та фізичні особи [10]. Замовниками проектної документації можуть бути органи державної влади, Рада міністрів Автономної Республіки Крим чи органи місцевого самоврядування, землевласники і землекористувачі.

Підставою для проведення інвентаризації масиву земель сільськогосподарського призначення є рішення сільської, селищної або міської ради, на території якої розташований масив. Масив земель сільськогосподарського призначення - сукупність земельних ділянок сільськогосподарського призначення, що складаються із сільськогосподарських і необхідних для їхнього обслуговування несільськогосподарських угідь (земель під польовими дорогами, меліоративними системами, господарськими шляхами, прогонами, лінійними об'єктами, об'єктами інженерної інфраструктури, а також ярами, заболоченими землями, іншими угіддями, які розташовані всередині земельного масиву), мають спільні межі й обмежені природними та/або штучними елементами рельєфу (автомобільними дорогами загального користування, полезахисними лісовими смугами та іншими захисними насадженнями, водними об'єктами тощо) [10].

Надання в оренду земельних ділянок під полезахисними лісовими смугами проводиться відповідно до ч. 3 ст. 124, ст. 123 ЗКУ і передбачає такі етапи:

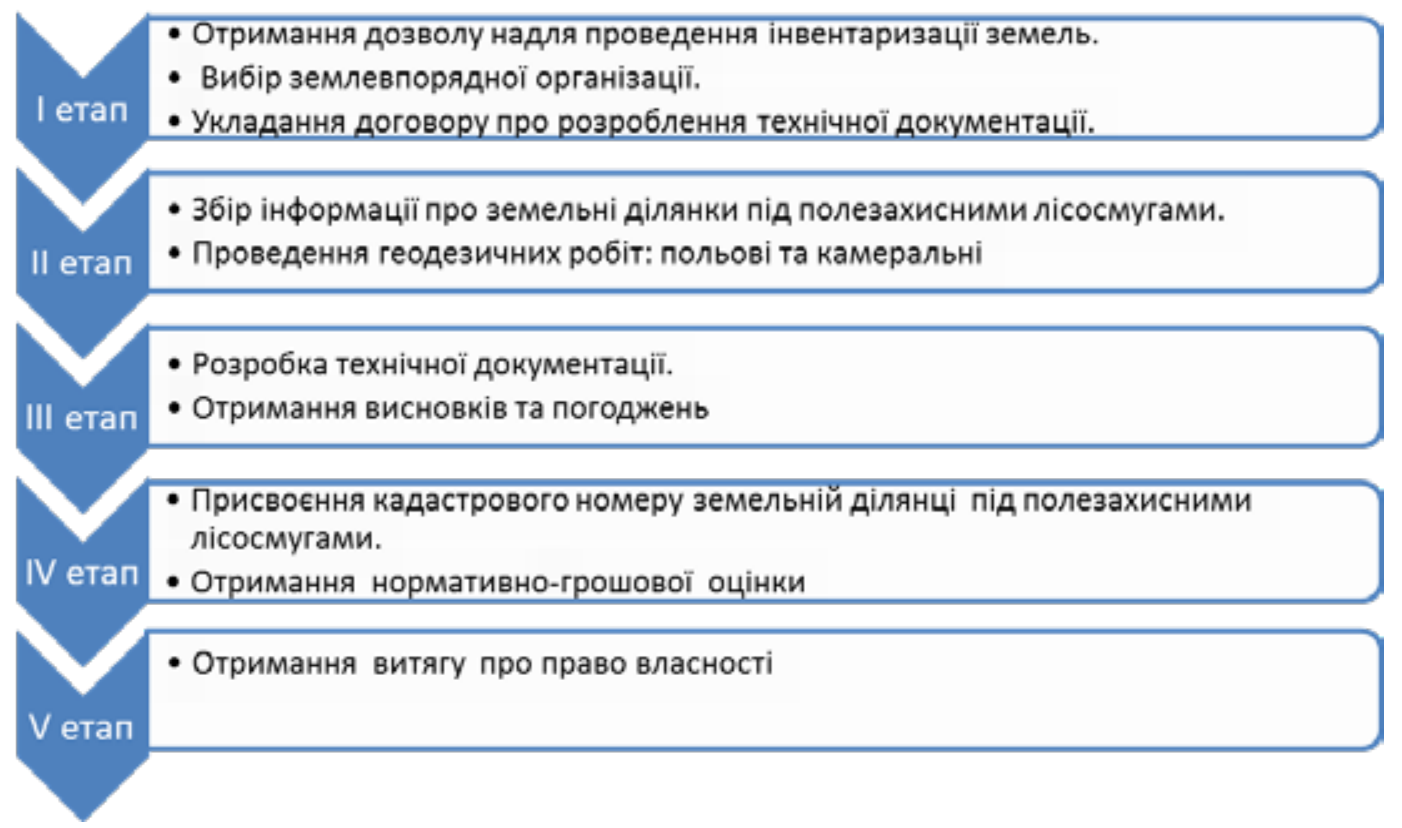

Рис. 1. Схема проведення інвентаризації земельних ділянок під лісосмугами 
- отримання дозволу на розроблення проектної документації із землеустрою щодо відведення земельної ділянки в оренду;

- отримання рішення органу місцевого самоврядування;

- розробка проектної документації землевпорядною організацією;

- державна реєстрація земельних ділянок у ДЗК;

- затвердження проекту відведення й отримання рішення про передачу в оренду;

- укладання договору оренди та реєстрація його відомостей у реєстрах майнових прав.

Зазначимо, що сьогодні уряд затвердив правила утримання та збереження полезахисних лісових смуг, розташованих на землях сільськогосподарського призначення. Документом визначено процедуру утримання та збереження полезахисних лісових смуг. Передбачено обов'язковість виконання Правил усіма власниками, орендарями та користувачами земельних ділянок, на яких розміщено полезахисні лісові смуги. Механізм проведення заходів залежить від показників характеристики лісомеліоративного стану насаджень, від виду, конструкції, вікового періоду, лісівничо-меліоративної оцінки. Поліпшення якісних показників, біологічної стійкості та меліоративної ефективності лісосмуг включає комплекс заходів (зріджування у процесі рубок догляду, рубки, пов'язані з реконструкцією, створення (відновлення), агротехнічний догляд і доповнення, збереження від пожеж, незаконних рубок, пошкодження, ослаблення та іншого шкідливого впливу, захист від шкідників і хвороб). Правила встановлюють умови негативного впливу на збереження та використання полезахисних лісових смуг [11].

Висновки. Агролісомеліорація відповідно до закону «Про меліорацію земель» належить до одного 3 основних видів меліорації земель. Аналітичний огляд літературних джерел показує, що найбільший меліоративний вплив захисного лісорозведення проявляється за наявності на території закінченої взаємодії та взаємозалежності системи лісових смуг. Проявляється виняткова роль захисних насаджень у підтриманні екологічної рівноваги. Створені на відкритих сільськогосподарських землях, вони перетворюють аграрний ландшафт на лісоаграрний, істотно збагачуючи його, змінюючи екологічні умови вирощування сільськогосподарських культур.

Зміни в положеннях земельного законодавства закріпили правовий статус лісосмуг, визначили їхню належність до земель сільськогосподарського призначення комунальної власності. Ці норми надали можливість передавати їх у постійне користування та в оренду за умови обов'язкового догляду за лісосмугою.

Встановлено, що стан захисних лісових насаджень $є$ незадовільним. Насадження нерідко забруднені побутовими та промисловими відходами, пошкоджені пожежами, самовільними рубками. Основна частина їх не має господаря. Тому затверджені правила утримання та збереження полезахисних лісових смуг, розташованих на землях сільськогосподарського призначення, забезпечать раціональне, невиснажливе використання захисних лісових насаджень.

\section{Список використаних джерел:}

1. Близнюк В. Ерозія грунтів переходить у наступ. URL: http://aphd.ua/pryklady-oformlennia-bibliohrafichnoho-opysuvidpovidno-do-dstu-83022015/

2. Закон України «Про меліорацію земель». URL: https://zakon.rada.gov.ua/laws/show/1389-14\#text

3. Наказ Державного агенства земельних ресурсів України «Про затвердження методичних рекомендацій щодо розроблення проектів землеустрою, що забезпечують еколого-економічне обгрунтування сівозміни та впорядкування угідь» від 2 жовтня 2013 р. № 396.

4. Локтєва-Маклашова Н.В., Майстренко М.О. Новели законодавства України щодо врегулювання правового режиму полезахисних лісових смуг та земельних ділянок під ними. Актуальні проблеми вітчизняної юриспруденції. Спецввипуск. 2019. С. 83-86.

5. Закон України від 10 липня 2018 р. № 2498-VIII «Про внесення змін до деяких законодавчих актів України щодо вирішення питання колективної власності на землю, удосконалення правил землекористування у масивах земель сільськогосподарського призначення, запобігання рейдерству та стимулювання зрошення в Україні». URL: http://zakon.rada.gov.ua/laws/show/2498-19.

6. Лісовий кодекс України від 21 січня 1994 р. № 3852-XII змінами та доповненнями. URL: http://zakon.rada.gov.ua/ laws/show/3852-12.

7. Осадча Н. Правовий статус лісосмуг в Україні: як юридично рятувати нашу екологію. URL: https:/ldaily.ua/news/ novosti/pravovyj-status-lisosmug-v-ukrayini-yak-yurydychno-ryatuvaty-nashu-ekologiyu/.

8. Земельний кодекс України від 25 жовтня 2001 р. № 2768-III із змінами та доповненнями. URL: http://zakon.rada.gov.ua/laws/show/2768-14/ed20190101\#n1042.

9. Закон України від 22 травня 2003 р. № 858-IV «Про землеустрій». URL: https://zakon.rada.gov.ua/laws/ show/858-15\#Text.

10. Постанови КМУ від 05 червня 2019 р. № 476 «Про затвердження Порядку проведення інвентаризації земель та визнання такими, що втратили чинність, деяких постанов Кабінету Міністрів України». URL: https://zakon.rada.gov.ua/ laws/show/476-2019-\%D0\%BF\#Text.

11. Про затвердження Правил утримання та збереження полезахисних лісових смуг, розташованих на землях сільськогосподарського призначення. URL: https://www.openforest.org.ua/140077/. 